\title{
The Effect of Pop Up Book Activities On Group A's Early Childhood Creativity
}

\author{
Anisa Fera Hidayah ${ }^{1}$
}

1PG PAUD FKIP Universitas Muhammadiyah Surakarta

\section{ABSTRACT}

This research shows determine whether there is influence of activity pop up book to the creativity of children ages early in TK Pertiwi Kwarasan Years Doctrine 2018/2019. Based on the results of the research can be concluded that the activities of the pop-up book effect on the creativity of children aged early group A. The results of the analysis of the data of research that has been carried out, obtaining the results of scores observation of early development of the creativity of the child before conducted an experiment with the activities of the pop-up book is amounted to 169 with an average of 15.36, the value of the highest 21 , the value of the lowest 12 and Standar Deviation $=3.264$.

\section{KEY WORDS}

pop up book, creativity, early childhood, activities, education

\section{CORRESPONDING AUTHOR:}

email: anisafera1012@gmail.com

Manuscript submitted May 21, 2020; accepted June 17, 2020.

Copyright: (C2020 This is an open access article under the terms of the Creative Commons Attribution License, which permits unrestricted use, distribution, and reproduction in any medium, provided the original author and source are credited.

\section{INTRODUCTION}

According to Law No. 20 Year 2003 on System of National Education, education is the business conscious and planned to realize an atmosphere of learning and the process of learning so that participants learners are actively developing the potential for him to have the strength of spiritual religion, control of self, personality, intelligence, morals noble , as well as skills which is needed by himself, society, nation and state. Education organized by giving exemplary, build a whim, and develop the creativity of the participants
ECRJ (Early Chilhood Research Journal)

ISSN Numbers: Print, 2655-6448; Online, 2655-9315

\section{ADDRESS}

Website: http://journals.ums.ac.id/index.php/ecrj

Address: Pendidikan Guru PAUD

Universitas Muhammadiyah Surakarta

A. Yani Street No. 1, Pabelan, Kartasura, Surakarta, Indonesia Telp. +62-271-717417 ext.

Email: ecrj@ums.ac.id

learners in the process of learning ( National Education , 2003: 4).

Children Education Age Dini is an attempt guidance which is intended for children from birth until the age of 6 ( six ) years were done through the provision of design education to assist the growth and development of the physical and spiritual so that children have the readiness to enter the education is more advanced . ( Ministry of Education and Culture No. 137 of 2014).

Unit or program of early childhood education is the service early childhood conducted in a institution of education in the 
form of Kindergarten (TK) / raudatul RA (RA) / Bustanul RA (BA), Group Play (KB), Wildlife Care Center (TPA), and Unit PAUD Similar (SPS).

Education of children aged early is believed to be the basis for the preparation of source power human being who qualified in time to come. By because the service early childhood education should be designed with carefully and with attention to the development of the child, changes in science knowledge and technology and culture are evolving .

Growth and development are achieved is the actualization of the potential of all aspects of the development of the child is optimal at every stage of its development. The level of development attainment illustrates the growth and development that is expected to be achieved by children in a certain time span .

The level of achievement of child development includes aspects of understanding religious and moral values, physical-motor, cognitive, language, as well as social-emotional and artistic. All aspects of development are very important to be developed and is expected to evolve as balanced between aspects that one with aspects of the other. It is showing the importance of efforts to developing the potential of children, one of them the creativity that involved determining the success of the child later in the day .

Creativity is very important for life. According to Maslow (Munandar, 2014: 27) " Creativity is a need for fundamental human , which needs to be the embodiment of self and the needs of the most high for humans ". By because it is, with the creativity of a person can realize the work in the form of an idea that is new, the methods of new and products new in quality and beneficial to life. A work that is creative will give satisfaction to the self itself that is not infinite value.

Qualities the nature of nature's fundamental is this that must be constantly nurtured and developed by teachers so that the nature of the creative they are not lost . In the development of creativity since age early role of educators are the parents and teachers is very important. At school the teacher is tasked with stimulating and fostering creativity development in children. Every child that is born has the potential creativity. The potential of creativity needs to be developed from an early age. If the creativity of children is not developed since age early then the creativity of children will berkemang less than optimal so that children do not pour the idea - the idea of a new, not be trained resolve the problem, not to explore, and have not been able to be creative. So that children's creativity can develop optimally, creative efforts are needed starting with understanding by the teacher relating to the development of children's creativity .

Based on the observations were carried out by researchers at TK Pertiwi Kwarasan when study showed that, the creativity of children in group A have not been grown in optimal. It is can be seen when learning to draw is still very monotonous and always should be in accordance with the color of her . When coloring a picture, the child has not been creative in accordance with his wishes, the child is still in required to coloring in accordance with an example . 
Activity Another may indicate that the creativity of the child has not grown in optimum is when the drawing is free, many children are still emulate the image in accordance with an example. They have not been able to create their own to draw freely according to their imagination .

In Group A consisted of 11 students, only there are six children who can draw and color the picture with a color that is in accordance with his will. They draw and combine colors to mengahsilkan color of the new that is more diverse. Of all the six children it is proven that the children are already able to create by drawing various kinds of fruit and coloring to create combinations of colors are attractive . While other children are less creative when drawing and coloring .

At the time of question and answer, six children are already able to communicate the images are made. While the kids the other was answered by mimicking answers his friend and there were silent when the teacher asked the children . It is demonstrated that the creativity of children in kindergarten Pertiwi Kwarasan group $A$ has not evolved as optimal.

Based on this problem teachers and researchers feel it is necessary to improve creativity in learning in Pertiwi Kwarasan Kindergarten . Teachers and researchers choose one of the activities of the learning that is interesting and different from the previous to develop the creativity of children, namely the activities of pop-up book.

The role of the media in the learning process is very important. The existence of media can support the learning process, make it easier for students to understand learning material, and improve the quality of teaching of teachers which will have an impact on the quality of student learning outcomes. Media differentiated into media two- dimensional media and three- dimensional. One of the three- dimensional media is Pop-Up Book.

\section{Creativity Study}

a. Understanding Creativity

According Monstakis ( Rachmawati and Kurniati , 2011: 13-14) says that creativity is an experience in mengeskpresikan and actualize the identity of the individual in the form of integrated between the relationship of self themselves, nature, and others. Understanding creativity by Monstakis emphasize the actualization of self ( realizing the potential ) in the environment around . While Semiawan (Rachmawati and Kurniati , 2011: 14) argues " creativity is the ability to provide new ideas and apply them in problem solving ". The definition of creativity by Semiawan emphasize the ability of creating the idea of a new. According Wahyudin (Susanto, 2017: 55) mentions krativitas is a power reserved in the sense of the broadest, which combines thought, imagination, ideas, and feelings are satisfactory. While it is, in the Dictionary of the Indonesian (KBBI), creativity is defined as the ability to create or power of copyright. The meaning of creativity is defined as the ability of a person or individual in creating or generating the creation of new, find a way just to do something in order to be easily, efficiently, and effectively. Creativity is also usually interpreted as an effort to develop old ways or old inventions that are considered old or out of date and no longer effective. From 
some understanding of the above can be concluded creativity is a capability that is owned by someone to create an idea, method , and product new which is expected to be useful in various fields in order to help resolve the problems in life .

\section{b. Creativity aspects}

According to Parnes ( Nursisto , 2000: 31) include :

1) Fluency ( fluency), namely the ability to express ideas to solve a problem .

2) Flexibility ( flexibility), ie the ability to produce various kinds of ideas in order to solve a problem outside of the category of the ordinary.

3) Originality ( authenticity ), namely the ability to provide a response unique.

4) Elaboration ( of detail ), namely the ability to express the direction of the idea of perpetually detailed to realize the idea become a reality .

5) Sensitivity ( sensitivity ), namely sensitivity in capturing and producing problems in response to a situation .

\section{c. Characteristics of Creativity}

One of the things that is important in the float creativity needs to know the characteristics of which appear on the child if the child it can be said as a child that is creative. The characteristics of creativity according to Supriadi (Rachmawati and Kurniati , 2011: 1516) are as follows :

1) Have a sense of want to know that high. Children's creative can have a sense of want to know that high with something that is new is known. Children who are creative will stop looking out of things the new time is already getting answers on a sense of curiosity.

2) Have original ideas.

Children who are creative will have an idea of its own that is different to the child that the other. With the idea itself this child will give birth to the work of the different or original .

3) Independent in carrying out activities. Children who are creative do activities without assisted by people around him . Kids had the idea of creative that makes a child $\mathrm{m}$ ampu perform activities without relying to others.

4) Having your own opinion that is not influenced by others.

Children who are creative will dare to express his opinion based on the known child without affected other people in front of the audience public.

5) Has the attitude of believing themselves are high.

Children who are creative will dare to express themselves and have confidence that it can complete the job that faced with completely .

d. Supporting and inhibiting factors of creativity. Factors driving and inhibiting creativity according to Rachmawati and Kurniati (2011: 27-32) there are four as follows:

1) Mental Stimulation.

Creative will arise if the child gets supportive mental stimulation. In the aspect of the personality of the child is stimulated to develop various kinds of potential personal creative as trust myself , courage, endurance themselves, and 
others so on. In the aspect of an atmosphere of psychological ( psychological athmosphere) is stimulated so that children have a sense of safe, love affection and acceptance. Accepting children with all the drawbacks and advantages will make the child brave try, initiative, and do something as spontaneous. This attitude is very necessary in the development of creativity. Without positive mental support, children's creativity will not be formed.

\section{2) Climate and Environmental Conditions.}

The condition of the environment in the surrounding child very influential large in foster creativity . Environment that is cramped, stuffy and drab would seem grim , is not excited and collect ideas brilliant . Creativity by itself will die and do not evolve with the condition of the environment that does not support.

\section{3) The Role of the Teacher.}

The teacher is a significant character in a child's life. Teachers holding role is more than just a teacher, but an educator in the sense that is true. Teachers are creative are teachers who are creative able to use a variety of approaches in the activity of learning to teach in developing their students. The teacher is a figure who likes to do creative activities in his life .

\section{4) The Role of Parents}

According to Munandar in Rachmawati and Kurniati (2011: 32) explains the attitude of parents who support the growth of creativity, as follows : a) Respect the opinions of children and encourage them to express .

b) Giving time to the children to think , contemplate, and delusional .

c) Allow children to make their own decisions .

d) Encourage children to explore and question things .

e) Convince the child that the parents appreciate what that want to try, do , and what are generated.

f) Support and encourage children's activities .

g) Enjoying its presence with children .

h) Giving praise the earnest to the child .

i) Encourage children's independence at work.

j) Establish a relationship working together that is good with children .

\section{e.Indicator of Creativity}

Indicators are used in the research is to use the characteristics of children's creative by Supriyadi ( Rachmawati and Kurniati, 2011: 1516), namely :

1) Have a sense of want to know that high .

2) Have original ideas .

3) Independent in carrying out activities

4) Having your own opinion that is not influenced by others.

5) Has the attitude of believers themselves are high .

\section{Study Pop Up Book}

The role of the media in the learning process is very important. The existence of media can support the learning process, make it easier for students to understand learning material, 
and improve the quality of teaching of teachers which will have an impact on the quality of student learning outcomes. Media differentiated into media two- dimensional media and three- dimensional. One of the three- dimensional media is Pop-Up Book .

According Dzuanda (2011: 1) Pop-Up Book is a book that has a part that can move or have elements of three -dimensional and provide visualization of the story that is interesting, ranging from the display image that can be moved when the page is opened .

According to Dzuanda (2011: 23), there are various types of pop-up books, some of which are transformations of pop-ups, tunnel pop-up books, Volvelles pop-ups, Movable pop-ups, Pull-tabs and Pop- outs.

According to Wikipedia, the term pop-up book is often used for each book threedimensional or book move, although the term commonly book moves include pop-ups, transformations, books tunnel, volvelles, flaps, pull-tabs, pop-outs, pull-down, and others, each of which is done by means that different .

Based on the description above, can be summed up book pop-up is a book that has a part that can move or element of three dimensional. Pop up books provide a more interesting visualization of the story. The book is also giving surprises in each page which can invite amazement when the page is opened, in addition to the pop-up book has a display image that is beautiful and can be enforced. So the pop-up book media is very suitable to be used as a teaching aid in kindergartens. Besides that, the process of learning by using media pop-up book would be much more fun .
Benefits of Pop Up : Dzuanda (2011: 5-6) media pop-up book has a wide range of benefits that are very useful, namely :

1) Teach children to better appreciate the books and treat it with more good .

2) Moving the child with the parents because of the pop-up book has a section that is smooth so that gives an opportunity for the parents to sit together with the sons and daughters of them and enjoy the story ( closer the relationship between the parent and child).

3) Developing children's creativity .

4) Stimulate children's imagination .

5) Adding knowledge to provide a description of the shape of an object ( object recognition).

6) Can be used as a medium to instill children's love of reading.

The steps to make a pop up book:

The steps in making this pop up book are taken from the site on the internet: https://id.wikihow.com/Creating-Books-PopUp

1) Fold a piece of paper that is solid into two parts at large. You can use a piece of construction / craft paper that is $23 \times 30 \mathrm{~cm}$ in size, but you can also use rigid paper / cardboard, thin poster paper, or decorative / patched paper for scrapbooks of all sizes .

2) Cut the two parts are horizontal and parallel to the part of the middle of paper to create a gap. The gap should be about $5 \mathrm{~cm}$ in length and width of approximately $2.5 \mathrm{~cm}$. This gap will become a pop-up anchor.

3) Create your illustration. You can draw and color the illustrations on paper construction 
or paper rigid / carton another, or you can cut out pictures from photos, magazines, or books picture recycling reset and paste in paper cartons are more sturdy .

4) Make the pages as needed. Use the technique of folding and cutting the same to make the pages as you need to bring the story was to end .

5) Write the reading text . Open each page and write or paste text at the bottom of each page .

6) Decorate the background of each page . Make a sketch of the background behind using a pencil before coloring them with a method of staining choice you. Leave the pop-up holder blank / not colored .

7) Cut and paste your pictures on the pop-up holders. Cut out the pictures and illustrations that you make. Give the glue on the part of the back of each picture and paste it at retaining the suit . However, don't let the image get stuck to the background of the page. Image was not going to jump out .

8) Bring your pages together. The pages must be posted on the back to the back of the other pages. The upper half of the outer side of the second page will be affixed to the bottom half of the outer side of the first page. Half part on the outside of the page three will be affixed on the half section under the exterior of the page kedua.Lanjutkan patterns of this until all pages attached to pages other.

9) Make the outer cover of the book. Fold a piece of paper sturdiness that a little more substantial than the whole book. Insert the paper that is folded earlier in the book , ornamental piece front and rear side of the outer cover, and then paste the parts inside the cover that is part of the future with the page first book and part of the back to page last book .

\section{Role Pop Up Book Of Creativity:}

The op up book gives a more interesting visualization of the story. Media is also giving surprises in each page which can invite amazement when the page is opened, in addition to the pop-up book has a display image that is beautiful and can be enforced. So the pop-up book media is very suitable to be used as a teaching aid in kindergartens. Besides that, the process of learning by using media pop-up book would be much more fun .

Through the activities of the pop-up book is the teacher can train the child to behave creatively, because the activities it frees the child to choose a picture of what just that will be in paste to create a pop-up book is. By freeing children to be creative and express their ideas, of course, will have a great influence on children's development .

By because it is a pop-up book is very instrumental important and can impact on the creativity of the child as through activities pop up book teachers can stimulate the child to create a work that is original and innovative through the activities of the pop-up book is .

\section{RESEARCH METHOD}

The type of research that is used by researchers in studies of this is the type of research quantitatively. Research is using the design of pre-experimental with the model 
design prates- post-test one group. This research was conducted in group A TK Pertiwi Kwarasan which is located in Kwarasan Village, Juwiring District. The population of the research this is the institution or agency that used researcher to conduct research. The sample in this study were children who were in Group A TK Pertiwi Kwarasan with the number of respondents in group A 11 children. The sampling technique used in this study is a type of nonprobability sampling technique that is saturated sampling technique .

\section{RESULTS AND DISCUSSION}

The results of data analysis using t-test obtained t- count of -23.220 . While $t$ table can be obtained through the table value of criticism distribution $t$ with a value of $\mathrm{df}$ or $\mathrm{db}$ $=10$ and $\mathrm{A} / 2$ or $0.050 / 2=0.025$ which shows $\mathrm{t}$ table amounted to 2,228 based on a comparison between $t$ arithmetic and t table can be known that the value of $t$ arithmetic amounted to - $23.220 \leq \mathrm{t}$ table is -2.228 and obtained values of significance $0.001<0.05$ then $\mathrm{H} \mathrm{O}$ is rejected and $\mathrm{H} 1$ accepted, then it can be concluded that there is the influence of activity pop up book to the creativity of children aged early group A in TK Pertiwi Kwarasan the teachings 2018 / 2019 is significant .

Supriya ( Rachmawati and Kurniati , 2011: 15-16) explains that the characteristics of creativity consists on : 1) Have a sense of want to know that high that a kid creative can have a sense of want to know that high with something that is new is known . 2) Has the idea of an original that is a kid that creative will have an idea of its own that is different to the child that the other. With the idea itself this child will give birth to the work of the different or original . 3) Independent in carrying out activities, that is, children who are creative in carrying out activities without the assistance of those around them. Kids have a gaga san creative that makes a child $\mathrm{m}$ ampu perform activities tan pa dependent to others. 4) Has the opinion itself ya ng not affected others, namely children whose creative will dare to express his opinion based on the known child without affected other people in front of the audience public . 5) Having a high selfconfidence that is a creative child will dare to express himself and have confidence that he can complete the work that is faced with completely .

Based on the comparison of the results of observations beginning and observation end ( attachment 9) seen that the results of observation of the end is high compared with observations beginning, all children experience an increase in the development of creativity . It is supporting the hypothesis which states that the activities of the pop-up book effect on the creativity of children aged early group $A$ in TK Pertiwi Kwarasan the teachings of 2018/2019 is significant .

\section{CONCLUSION}

Based on the results of the study it can be concluded that the pop-up book activities affect the creativity of early childhood group $A$ in TK Pertiwi Kwarasan 2018/2019 school year. This conclusion is based on the results of analysis of research data that have been done, obtaining the results of the initial observation 
score of the development of children's creativity before the experiment with the pop up book activity is 169 with an average of 15.36 , the highest value 21 , the lowest value 12 and $S D=3.264$. The final observation results of the development of children's creativity after the experiment obtained a score of 339 , with an average of 30.82 , the lowest value of 26 , the highest value of 38 and $S D=4.238$. Based on these data can be obtained $t$ count $-23,220 \leq t$ table-2.228 can be determined through an analysis of SPSS 15.0 for Windows and t table can be seen through the critical value distribution table $t$ value $\mathrm{df}$ or $\mathrm{db}=12$ and $\mathrm{A}$ / 2 or $0,050 / 2=0,025$, for a value of $t$ arithmetic $-23.220 \leq \mathrm{t}$ table -2.228 and the significance value $0.001<0.05$, then $\mathrm{H} 0$ is rejected and $\mathrm{H} 1$ accepted. So it can be concluded that the pop up book activity influences the creativity of group A children in TK Pertiwi Kwarasan 2018/2019 school year significantly.

\section{Implication}

The results of research conducted by researchers using pop up book activities have the following implications:

1. Event pop-up book can affect a child's creativity in TK Pertiwi Kwarasan, this statement can be seen through experiments conducted for 6 times, children have a better development of creativity seteleh given treatment by providing activities pop up book .

2. Event pop-up book that is given to children in group A at TK Pertiwi Kwarasan make children become more creative and able to create new works, and different from others.
3. Event pop-up book makes children have self-confidence, because in the event the child can menungkan his ideas in a handiwork.

4. Event pop-up book makes children more concentrated, because in making pop-up books a child should be made with care and caution in order to produce good work.

5. Event pop-up book make children have a high curiosity, because the form of pop-up book that uniquely make children increasingly want to know the contents inside the pop-up book.

\section{Suggestion}

Based on the results of the study, the discussion and conclusions that have been presented can be given some suggestions as follows:

\section{For Teachers}

Teachers should be more creative and innovative in developing learning media, so children can be interested and have a higher curiosity when participating in learning.

2. For Parents

Parents should establish good communication with the teacher. Thus parents can communicate the development of their children while at school and can provide stimulation when at home with games that are more interesting, fun and in accordance with the child's ability level, to enhance the development of children's creativity while at home.

\section{For Principals}

The principal is expected to be able to provide infrastructure and facilities to support children's creativity, as well as to hold outreach 
to parents about aspects of development that children have and must be developed.

4. For Future Researchers

It is hoped that this research can be used as a reference for other studies, bearing in mind that there are still many aspects of early childhood development that must be developed and stimulated properly.

\section{REFERENCES}

Arifin, Zainal. 2011. Penelitian Pendidikan. Bandung: Rosdakarya.

Arikunto, Suharsimi. 2010. Prosedur Penelitian Suatu Pendekatan Praktik. Jakarta: Rineka Cipta.

Darmadi, Hamid. 2013. Dimensi-Dimensi Metode Penelitian Pendidikan san Sosial. Bandung: Alfabeta.

Dzuanda, B. Perancangan Buku Cerita Anak Pop-up Tokoh-tokoh Wayang Berseri, Seri Gatotkaca.

http://digilib.its.ac.id/index.php November 2018

Munandar, Utami. 2002. Kreativitas dan Keberbakatan : Strategi Mewujudkan Potensi Kreatif \& Bakat. Jakarta: PT. Gramedia Pustaka Utama.

Munandar, Utami. 2014. Pengembangan Kreativitas Anak Berbakat. Jakarta: Rineka Cipta.

Nursisto. 2000. Kiat Menggali Kreativitas. Yogyakarta: Mitra Gama Media.

Nadya G Dula, Stefani. 2016. "Pengembangan Media Pop Up Book Pada Materi Bentuk Permukaan Bumi Untuk Siswa Kelas III". Jurnal Penelitian Universitas Negeri Semarang, 1(1): 48-50

Rachmawati, Yeni dan Kurniati, Euis. 2011. Strategi Pengembangan Kreativitas Pada Anak. Jakarta: Kencana.

Semiawan, Conny M. 2009. Kreativitas Keberbakatan : Mengapa, Apa, dan Bagaimana. Jakarta: PT Indeks.

Sugiyono. 2011. Metode Penelitian Kuantitatif Kualitatif Dan R \& D. Bandung: Alfabeta. 
Sukmadinata, Nana Syaodih. 2015. Metode Penelitian Pendidikan. Bandung: Rosdakarya.

Susanto, Ahmad. 2017. Pendidikan Anak Usia Dini. Jakarta: Bumi Aksara.

Sutama. 2015. Metode Penelitian Pendidikan. Surakarta: Fairuz Media.

Vanni, Astida Friyani. 2017. "Pengaruh Permainan Playdough Terhadap Kreativitas Anak Kelompok B di TK Pertiwi 2 Kahuman Polanharjo Klaten Tahun Ajaran 2016/2017" Jurnal Penelitian Universitas Muhammadiyah Surakarta. 